\title{
Endoscopic treatment of postoperative biliary fistulas
}

\author{
Şükrü Çolak, M.D., ${ }^{1}$ ำ Bünyamin Gürbulak, M.D., ${ }^{1}$ ○ Ali Fuat Kaan Gök, M.D., ${ }^{2}$ \\ (1) Ekrem Çakar, M.D., ${ }^{1}$ ○ Hasan Bektaş, M.D. ${ }^{1}$
}

1'Department of General Surgery, İstanbul Training and Research Hospital, İstanbul-Turkey

${ }^{2}$ Department of General Surgery, İstanbul University İstanbul Faculty of Medicine, İstanbul-Turkey

\begin{abstract}
BACKGROUND: Biliary fistula is one of the most common complications of liver and biliary tract surgeries. Endoscopic retrograde cholangiopancreatography (ERCP) is used for the diagnosis and treatment of biliary fistulas. In this study, we aimed to analyze the contribution of ERCP in this regard.
\end{abstract}

METHODS: Patients who underwent ERCP for biliary fistulas following liver and biliary tract surgery between January 2012 and December 2017 were included in this study. The demographic characteristics of the patient, surgical procedure, localization of the biliary fistula, classification of biliary duct injury, and success of ERCP were retrospectively evaluated.

RESULTS: In total, 90 patients ( 37 male and 53 female) with a diagnosis of biliary fistula underwent ERCP. Common biliary duct (CBD) cannulation was achieved in 87 patients using ERCP. In five patients, the proximal part of the biliary tract was not visualized, and complete injury of CBD was considered. In ERCP, contrast extravasation was detected in the cystic duct in 44 patients: CBD, eight patients; liver bed, four patients; hepatic duct bifurcation, two patients; the right hepatic canal, seven patients; and the left hepatic canal, two patients.

CONCLUSION: ERCP is an effective method for the diagnosis and treatment of biliary diseases. The diagnosis and treatment of postoperative biliary fistulas with ERCP reduces surgery cost, morbidity, and mortality.

Keywords: Biliary fistula; biliary stents; ERCP.

\section{INTRODUCTION}

Many complications occur following liver and biliary tract surgeries, which includes that wound site infections, iatrogenic vascular and biliary injuries, and anastomotic leakage. Generally, the biliary injuries are iatrogenic and may be noticed during operation or in the postoperative follow-up period. Most of the iatrogenic biliary tract injuries cannot be detected during surgery. ${ }^{[1]}$ Concerning mortality and morbidity, perioperative noticeable biliary injuries are more advantageous concerning managing the complication than those observed in the postoperative period. ${ }^{[2,3]}$ Biliary fistula most commonly occurs after cholecystectomy. The rate of biliary tract injuries observed during laparoscopic cholecystectomy is higher than that open cholecystectomy. ${ }^{[4,5]}$ The incidence of biliary injury in laparoscopic cholecystectomy has been reported to vary from $0.5 \%$ to $0.9 \%$ in different series. ${ }^{[6]}$ Biliary fistulas can be observed following liver resections, surgical procedures for hydatid cysts, blunt and penetrating liver injuries, and liver biopsies. Other causes includes that liver transplantation with biliary duct anastomosis and surgical interventions for periampullary tumors. The time, patient's condition, radiological and laboratory findings of biliary fistulas play an important role in the treatment strategy. Endoscopic retrograde cholangiopancreatography (ERCP) is an advanced endoscopic method used for the diagnosis and treatment of biliary tract and pancreatic diseases. This study aims to evaluate the contribution of ERCP in the

Cite this article as: Çolak Ş, Gürbulak B, Gök AFK, Çakar E, Bektaş H. Endoscopic treatment of postoperative biliary fistulas.

Ulus Travma Acil Cerrahi Derg 2020;26:103-108.

Address for correspondence: Bünyamin Gürbulak, M.D.

İstanbul Eğitim ve Araştırma Hastenesi, Genel Cerrahi Kliniği, 34090 Fatih, İstanbul, Turkey

Tel: +90 212 - 4883025 E-mail: bgurbulak@gmail.com

Ulus Travma Acil Cerrahi Derg 2020;26(I):103-108 DOI: 10.14744/tjtes.2019.63667 Submitted: 31.01.2019 Accepted: 15.03.2019 Online: 02.01.2020

Copyright 2019 Turkish Association of Trauma and Emergency Surgery 
diagnosis and treatment of patients admitted because of the biliary fistulas.

\section{MATERIALS AND METHODS}

This study included 90 patients who were diagnosed with biliary fistula following cholecystectomy or hepatobiliary surgery and had undergone an ERCP procedure in our endoscopy unit between January 2012 and December 2017. The patients were informed about biliary fistulas, treatment options, and ERCP complications; they were evaluated by an anesthesiologist based on the American Society of Anesthesiologists score. The type of sedation and dosage of medication were determined and administered under the control of the anesthesiologist. Age, gender, type of surgery, postoperative period, physical examination findings, and daily drainage (cc) of bile were recorded. Data regarding the cannulation rates of the common biliary duct (CBD) and pancreatic duct, location of the contrast extravasation, type of injury, filling defects in CBD, endoscopic treatment method, type and size of the endobiliary stents were recorded.

In the postoperative period, the type and time of radiological imaging were determined based on the amount of biliary fistula. A daily volume of 500 cc of biliary drainage was accepted as a threshold value based on the classical fistula flow definition. If the fistula flow rate and biochemical values were high, the patient was evaluated by upper abdominal magnetic resonance (MR) and MR cholangiography. If the fistula flow was low and continued for a few days, the patient was evaluated by abdominal ultrasonography (USG), and ERCP was performed. Fistulas were classified based on the level of contrast extravasation in ERCP. The Strasberg classification was used for iatrogenic biliary injuries during cholecystectomy (Table I). The treatment of patients was planned according to this classification. Preoperative anatomic localization, diameter, and type (based on the Gharbi classification) of the cyst were recorded in patients who underwent hydatid cyst surgery. The endoscopic treatment was considered successful if the cessation of biliary fistula and radiological, clinical, and laboratory findings of the patient were improved following the ERCP. Multiple ERCPs were performed for stent removal in patients and for those who developed a biliary stricture.

Informed consent was obtained from all the patients included in this study. The study was conducted, and data were collected according to the ethical principles of the Declaration of Helsinki.

\section{Statistical Methods}

Descriptive statistical methods, such as mean \pm standard deviation and/or median (minimum-maximum) and frequency and percentage, were used for data evaluation. The statistical analysis was performed using the Statistical Package for Social Sciences $\left(\right.$ SPSS $^{\circledR}$ ) software package for Windows, version 17.0 (SPSS Inc., Chicago, Illinois, USA).

\section{RESULTS}

A total of 90 patients comprising 37 (4I.1\%) males and 53 (58.9\%) females were admitted to the endoscopy unit with the diagnosis of postoperative biliary fistula. Overall, $54 \mathrm{pa}-$ tients were referred from other centers, and 36 patients were operated in our clinic. Biliary drainage was noted in 85 patients upon admission. The clinical symptoms of the patients most commonly included biliary fistula in 77 (85.5\%) patients, abdominal pain in 46 (51.1\%), jaundice in 25 (27.7\%), biloma in 10 (1I.1\%), and peritonitis in three (3.3\%). While 65 patients had normal liver function tests, 25 had elevated cholestasis enzymes and bilirubin levels.

CBD cannulation was achieved in 87 of patients but; it was not succesfully in two of patients because of pyloric stenosis

Table I. Strasberg classification

\begin{tabular}{lcccl}
\hline Type & \multicolumn{2}{c}{ Patients $(\mathbf{n})$} & $\%$ & Definition \\
\cline { 2 - 5 } & Female & Male & & \\
\hline A & 26 & 22 & 70.5 & Cystic duct or small biliary ducts in the liver bed \\
B & - & - & - & Occlusion of the aberrant right hepatic duct \\
C & - & - & - & Transection without ligation of the aberrant right hepatic duct \\
D & 9 & 6 & 22 & Lateral injury to the major bile duct \\
EI & 3 & 2 & 7.3 & Transection $>2$ cm from the hilum \\
E2 & - & - & - & Transection $<2$ cm from the hilum \\
E3 & - & - & - & Transection in the hilum \\
E4 & - & - & - & Separation of major ducts in the hilum \\
E5 & - & - & - & Type $C$ injury plus injury in the hilum \\
Total & 38 & 30 & & \\
\hline
\end{tabular}


Table 2. Age, gender, and ASA classification of patients

\begin{tabular}{lcc}
\hline & Female & Male \\
\hline Patient, n (\%) & $53(58.9)$ & $37(4 \mathrm{I} . \mathrm{I})$ \\
Age (years) & 50.47 & 55.02 \\
Cannulation of CBD, n (\%) & $52(98.1)$ & $35(94.6)$ \\
ASA I & 45 & 25 \\
ASA II & 7 & 9 \\
ASA III & 1 & 1 \\
\hline
\end{tabular}

ASA: American Society of Anesthesiologists; CBD: Common biliary duct.

Table 3. Patients and ERCP procedures

\begin{tabular}{lccc}
\hline & Female & Male & Total \\
\hline Hydatid cyst & 5 & 3 & 8 \\
Daughter cyst in CBD & 2 & 0 & 2 \\
ES/stenting & $5 / 2$ & $3 / I$ & $8 / 3$ \\
\hline Hepatectomy & 1 & 2 & 3 \\
ES/stenting & $1 / 1$ & $2 / 0$ & $3 / 1$ \\
\hline Metastasectomy & 0 & 1 & 1 \\
ES/stenting & $0 / 0$ & $1 / 1$ & $1 / 1$ \\
\hline Liver trauma & 0 & 1 & 1 \\
ES/stenting & $0 / 0$ & $1 / 0$ & $1 / 0$ \\
\hline Cholecystectomy & 47 & 29 & 76 \\
ES/stenting & $43 / 37$ & $26 / 17$ & $69 / 54$ \\
\hline Stone in CBD & 7 & 9 & 16 \\
Choledochotomy & 0 & 1 & 1 \\
ES/stenting & $0 / 0$ & $1 / I$ & $1 / 1$ \\
\hline ES: Endoscopic Sphincterotomy; ERCP: Endoscopic retrograde cholangiopancre- \\
atography; CBD: Common biliary duct. & & \\
& & & \\
\hline
\end{tabular}

and in one patient because of technical reasons. The biliary tract was normal, and no contrast extravasation detected in seven patients (Table 2). ERCP was performed in 76 (84.4\%) patients following cholecystectomy, eight (8.8\%) patients following hydatid cyst surgery, three patients following hepatic resection, one patient following metastasectomy, one patient with penetrating liver injury, and one patient with choledocholithiasis (Table 3).

While the distal biliary tract was imaged in five patients, the visualiation of the proximal part of it could not be imaged, and complete injury of CBD was considered. These five patients subsequently underwent percutaneous transhepatic biliary drainage under the guidance of USG.

In ERCP, extravasation of the contrast medium was detected in the cystic duct in 44 patients: CBD in eight, liver bed in
Table 4. Biliary stricture, multiple ERCPs, and stenting

\begin{tabular}{lccc}
\hline & Female & Male & Total \\
\hline CBD & 2 & 2 & 4 \\
Dilatation & 1 & 2 & $3 / 4$ \\
Multiple stenting & $\mathrm{I}$ & 2 & $3 / 4$ \\
SEMS & $\mathrm{I}$ & 2 & $3 / 4$ \\
Bifurcation & $\mathrm{I}$ & 0 & $\mathrm{I}$ \\
Dilatation & $\mathrm{I}$ & 0 & $\mathrm{I} / \mathrm{I}$ \\
Stenting & $\mathrm{I}$ & 0 & $\mathrm{I} / \mathrm{I}$ \\
Right hepatic duct & 2 & $\mathrm{I}$ & 3 \\
Dilatation & $\mathrm{I}$ & $\mathrm{I}$ & $2 / 3$ \\
Stenting & $\mathrm{I}$ & $\mathrm{I}$ & $2 / 3$ \\
\hline
\end{tabular}

SEMS: Self expandable metallic stent; ERCP: Endoscopic retrograde cholangiopancreatography; CBD: Common biliary duct.

four, hepatic duct bifurcation in two, the right hepatic canal in seven, and the left hepatic canal in two patients. Following hydatid cyst surgery, biliary fistula was present in eight patients, six fistulas were from the right hepatic lobe and two from the left hepatic lobe. According to the Gharbi classification, in the preoperative period, seven patients were classified as type 3 and one as type 2 .

Endoscopic sphincterotomy (ES) was not performed in three patients which could not be cannulated and in five patients with complete CBD injury. Eighty-two patients underwent ES and 59 underwent biliary stenting. Stents were removed in an average of 65 days (18-360 days). A biliary stricture developed in eight patients who had lateral injuries of the main biliary duct, which improved with a biliary stent. These patients underwent ERCP 3 to 7 times for the stricture. Plastic stents were used in seven patients, and self-expendable metallic stents (SEMS) were used in three patients (Table 4).

In our study, the most common biliary fistula was from the cystic duct and gallbladder bed following cholecystectomy. Low flow biliary fistula was detected in 67 (74.4\%) patients. The Strasberg Type A biliary duct injury was found in 48 (70.5\%) patients. Succesfully teratment was achieved for biliary fistulas in $79(88.8 \%)$ of patients who underwent ERCP.

\section{DISCUSSION}

Biliary fistulas can be observed in many procedures involving the liver and bile ducts. There is a correlation between biliary fistula and the operation. For example, the biliary fistula rate varies from $3.6 \%$ to $10 \%$ following hepatectomy, and the rate of biliary fistula has been reported to be $8 \%$ in hepaticojejunostomy with pancreaticoduodenectomy. ${ }^{[7,8]}$ The rate of biliary fistula and stricture were reported to be $8.5 \%$ and $14.7 \%$, respectively, after liver transplantation. ${ }^{[9]}$ The rate of the biliary fistula 
is reported to be $5 \%$ to $63 \%$ following hydatid cyst surgery ${ }^{[10,11]}$ and $0.5 \%$ to $21 \%$ following liver trauma. ${ }^{[12,13]}$

The incidence of biliary injury in laparoscopic cholecystectomy has been reported to vary between $0.5 \%$ to $0.9 \%$ in different series. The first laparoscopic cholecystectomy was performed by Erich Mühe in 1985..$^{[14]}$ The rate of biliary injury is higher in laparoscopic cholecystectomy than open cholecystectomy because of the 2-dimensional appearance and a longer learning curve. ${ }^{[15]}$ According to the principles of "critical view of safety," the dissection of the Calot's triangle should be carefully performed, and the gallbladder should be released from the liver bed. The cystic duct and artery should not be clipped and divided when the critical view of safety is not anatomically achieved. ${ }^{[16,17]}$ The mechanisms of these biliary tract injuries in laparoscopic cholecystectomy are well-defined. The most common condition is that the main biliary and cystic ducts cannot be identified because of the inability to dissect the Calot's triangle. This condition can be because of the congenital anatomical anomalies as well as severe adhesion caused by inflammation, obesity, and gallbladder neoplasm. ${ }^{[18-21]}$ Factors related to the skill and experience of the surgeon include unnecessary dissections of the Calot's triangle, use of cautery near the biliary ducts, and excessive traction of the gallbladder. ${ }^{[22]}$ Biliary fistulas can be observed after cholecystectomy because of the extra biliary ducts that directly opened to the gallbladder; Oddi sphincter dysfunction without biliary duct injury or various type of injuries in the biliary tract. If a biliary fistula occurs after a biliary duct injury, it may lead to a biliary duct stricture after recovery. The management of this complication is quite difficult for physicians. ${ }^{[23]}$ Biliary tract injury can be simple and treatable with a minimally invasive approach, such as ERCP, or may require a complex surgery because of high flow biliary fistula. Common symptoms of biliary fistulas include biliary drainage, abdominal pain, jaundice, fever, acid, and bilomas. Although most biliary fistulas are observed in the first week following surgery, this period may be extended up to three months. ${ }^{[24]}$ Radiological methods, such as USG, computerised tomography, MR cholangiopancreatography, can be used to evaluate the biliary fistulas. ERCP was first used as a diagnostic tool in 1968. The first biliary stent was used in a patient with jaundice in 1980. ${ }^{[25]}$ Thus, ERCP was used from the diagnosis to treatment stages. Recently, ERCP has an important role in the treatment of complications of surgery. The main functions of ERCP in biliary fistulas are to decrease the pressure in the biliary tract using sphincterotomy or biliary stents, prevent biliary leakage into the abdominal cavity, and direct the bile to the bowel lumen, which reduces the mortality and morbidity rates by protecting patients from localized and generalized peritonitis. The treatment approach in ERCP is determined by the type and localization of fistula in cholangiography, the amount of fistula (cc), stone and stricture associated with the injury. The most successful treatment of biliary fistulas is achieved through ERCP for the type of Strasberg A-D injuries. The most common cause of biliary fistulas was chole- cystectomy because of cholelithiasis in 76 patients (84.4\%). Four of these patients had a conversion from laparoscopic to open surgery. Choledocholithiasis was detected in $16(21 \%)$ of the 76 patients. This finding may be because of spontaneous passage of stone to $\mathrm{CBD}$ before the procedure or because these patients may have secondary Oddi sphincter dysfunction. The second most common cause was hydatid cyst surgery in eight (8.8\%) patients. Only two of these patients were detected with daughter cysts in $C B D$, which were extracted using ERCP. Hepatic resection was present in four (4.4\%) patients. One patient (I.1\%) had penetrating liver injury, and one (1.I\%) patient underwent choledochotomy for choledocholithiasis. In the patient who underwent choledochotomy, closure of the fistula failed because of a stricture in distal choledochotomy one month following the operation. A biliary stent was placed after sphincterotomy, and multiple dilatations were performed because of the stricture.

In our study, the most common location for biliary fistula was the cystic stump and gallbladder bed after cholecystectomy. Low flow biliary fistula was detected in 67 (74.4\%) patients. The Strasberg Type A bile duct injury was found in 48 (70.5\%) patients.

Eighty-two (91.1\%) patients underwent sphincterotomy, and $59(65.5 \%)$ patients underwent biliary stenting. Eight patients with an injury of the right hepatic duct and two patients with an injury of bifurcation had 8.5 French $12-\mathrm{cm}$ plastic biliary stents placed in both the right and left main hepatic ducts. For the other patients, 10 French $10-\mathrm{cm}$ plastic biliary stents were used.

Animal studies that evaluated the pressure gradient between CBD and the duodenum after sphincterotomy or stenting and have shown that the intrabiliary pressure was more effectively decreased in the stenting group than the ES group. ${ }^{[26]}$ Other clinical and experimental studies have shown that biliary stenting with ES is more effective than ES alone in reducing the Oddi sphincter pressure. ${ }^{[27,28]}$

The efficacy of ERCP in biliary injuries, leading to biliary fistulas, is reported to be $85 \%-95 \% .{ }^{[29,30]}$ The efficacy of ERCP in postoperative biliary fistulas was $88.8 \%$ in our series. Data regarding the stricture formation of the bile duct after the improvement of injuries are limited. In our series, 28 patients had major biliary tract injuries. Fifteen of these patients had a lateral injury of CBD, and these patients were treated without complications by ERCP. In eight of these patients, a stricture developed in CBD. For these patients, multiple dilatations and plastic biliary stenting were performed, and SEMS were used in two patients.

In conclusion, postoperative biliary fistulas are complications that may be associated with high mortality and morbidity. Our experiences showed that ERCP was an effective method for diagnosing and treating the biliary fistulas following surgery. 
ERCP assists in managing the biliary duct strictures, prevents additional operations, and offers significant advantages concerning mortality, morbidity, and cost.

Ethics Committee Approval: Retrospective study.

Peer-review: Internally peer-reviewed.

Authorship Contributions: Concept: Ş.Ç., H.B.; Design: Ş.Ç., B.G.; Supervision: H.B.; Materials: Ş.Ç., E.Ç.; Data: Ş.Ç., E.Ç.; Analysis: A.F.K.G., B.G.; Literature search: A.F.K.G., B.G.; Writing: B.G., Ş.Ç.; Critical revision: B.G., H.B.

Conflict of Interest: None declared.

Financial Disclosure: The autors declared that this study has received no financial support.

\section{REFERENCES}

1. Bergman JJ, van den Brink GR, Rauws EA, de Wit L, Obertop H, Huibregtse K, et al. Treatment of bile duct lesions after laparoscopic cholecystectomy. Gut 1996;38:141-7.[CrossRef]

2. Martin RF, Rossi RL. Bile duct injuries. Spectrum, mechanisms of injury, and their prevention. Surg Clin North Am 1994;74:781-807. [CrossRef]

3. Sandha GS, Bourke MJ, Haber GB, Kortan PP. Endoscopic therapy for bile leak based on a new classification: results in 207 patients. Gastrointest Endosc 2004;60:567-74. [CrossRef]

4. Roslyn JJ, Binns GS, Hughes EF, Saunders-Kirkwood K, Zinner MJ, Cates JA. Open cholecystectomy. A contemporary analysis of 42,474 patients. Ann Surg 1993;218:129-37. [CrossRef]

5. Strasberg SM, Hertl M, Soper NJ. An analysis of the problem of biliary injury during laparoscopic cholecystectomy. J Am Coll Surg 1995;180:101-25.

6. Adamsen S, Hansen OH, Funch-Jensen P, Schulze S, Stage JG, Wara P. Bile duct injury during laparoscopic cholecystectomy: a prospective nationwide series. J Am Coll Surg 1997;184:571-8.

7. Ishii H, Ochiai T, Murayama Y, Komatsu S, Shiozaki A, Kuriu Y, et al. Risk factors and management of postoperative bile leakage after hepatectomy without bilioenteric anastomosis. Dig Surg 2011;28:198-204.

8. Qiu H, Zhang J, Qian HG, Leng JH, Wu JH, Liu BN, et al. Hepaticojejunostomy leak after pancreaticoduodenectomy. Int Surg J 2016;3:603-8.

9. Nemes B, Gámán G, Doros A. Biliary complications after liver transplantation. Expert Rev Gastroenterol Hepatol 2015;9:447-66. [CrossRef]

10. Kayaalp C, Bzeizi K, Demirbag AE, Akoglu M. Biliary complications after hydatid liver surgery: incidence and risk factors. J Gastrointest Surg 2002;6:706-12. [CrossRef]

11. Adas G, Arikan S, Gurbuz E, Karahan S, Eryasar B, Karatepe O, et al. Comparison of endoscopic therapeutic modalities for postoperative biliary fistula of liver hydatid cyst: a retrospective multicentric study. Surg Laparosc Endosc Percutan Tech 2010;20:223-7. [CrossRef]

12. Christmas AB, Wilson AK, Manning B, Franklin GA, Miller FB, Richardson JD, et al. Selective management of blunt hepatic injuries including nonoperative management is a safe and effective strategy. Surgery 2005;138:606-10. [CrossRef]

13. Asensio JA, Roldán G, Petrone P, Rojo E, Tillou A, Kuncir E, et al. Operative management and outcomes in 103 AAST-OIS grades IV and V complex hepatic injuries: trauma surgeons still need to operate, but an- gioembolization helps. J Trauma 2003;54:647-53; discussion 653-4.

14. Litynski GS. Highlights in the History of Laparoscopy. Frankfurt, Germany: Barbara Bernert Verlag; 1996. p. 165-8.

15. Roy PG, Soonawalla ZF, Grant HW. Medicolegal costs of bile duct injuries incurred during laparoscopic cholecystectomy. HPB (Oxford) 2009;11:130-4. [CrossRef]

16. Wu YV, Linehan DC. Bile Duct Injuries in the era of laparoscopic cholecystectomies. Surg Clin North Am 2010;90:787-802. [CrossRef]

17. Buddingh KT, Morks AN, ten Cate Hoedemaker HO, Blaauw CB, van Dam GM, Ploeg RJ, et al. Documenting correct assessment of biliary anatomy during laparoscopic cholecystectomy. Surg Endosc 2012;26:79-85. [CrossRef]

18. Larson GM, Vitale GC, Casey J, Evans JS, Gilliam G, Heuser L, et al. Multipractice analysis of laparoscopic cholecystectomy in 1983 patients. Am J Surg 1992;163:221-6. [CrossRef]

19. Scott TR, Zucker KA, Bailey RW. Laparoscopic cholecystectomy: a review of 12,397 patients. Surg Laparosc Endosc 1992;2:191-8.

20. Krähenbühl L, Sclabas G, Wente MN, Schäfer M, Schlumpf R, Büchler MW. Incidence, risk factors, and prevention of biliary tract injuries during laparoscopic cholecystectomy in Switzerland. World J Surg 2001;25:1325-30. [CrossRef]

21. Barkun AN, Rezieg M, Mehta SN, Pavone E, Landry S, Barkun JS, et al. Postcholecystectomy biliary leaks in the laparoscopic era: risk factors, presentation, and management. McGill Gallstone Treatment Group. Gastrointest Endosc 1997;45:277-82. [CrossRef]

22. Malik AM, Laghari AA, Talpur AH, Khan A. Iatrogenic biliary injuries during laparoscopic cholecystectomy. A continuing threat. Int J Surg 2008;6:392-5. [CrossRef]

23. Rerknimitr R, Sherman S, Fogel EL, Kalayci C, Lumeng L, Chalasani $\mathrm{N}$, et al. Biliary tract complications after orthotopic liver transplantation with choledochocholedochostomy anastomosis: endoscopic findings and results of therapy. Gastrointest Endosc 2002;55:224-31. [CrossRef]

24. Davidoff AM, Pappas TN, Murray EA, Hilleren DJ, Johnson RD, Baker $\mathrm{ME}$, et al. Mechanisms of major biliary injury during laparoscopic cholecystectomy. Ann Surg 1992;215:196-202. [CrossRef]

25. Soehendra N, Reynders-Frederix V. Palliative bile duct drainage - a new endoscopic method of introducing a transpapillary drain. Endoscopy 1980;12:8-11. [CrossRef]

26. Katsinelos P, Kountouras J, Paroutoglou G, Chatzimavroudis G, Germanidis G, Zavos C, et al. A comparative study of 10-Fr vs. 7-Fr straight plastic stents in the treatment of postcholecystectomy bile leak. Surg Endosc 2008;22:101-6. [CrossRef]

27. Youngelman DF, Marks JM, Ponsky T, Ponsky JL. Comparison of bile duct pressures following sphincterotomy and endobiliary stenting in a canine model. Surg Endosc 1997;11:126-8. [CrossRef]

28. Kim KH, Kim TN. Endoscopic management of bile leakage after cholecystectomy: a single-center experience for 12 years. Clin Endosc 2014;47:248-53. [CrossRef]

29. Kaffes AJ, Hourigan L, De Luca N, Byth K, Williams SJ, Bourke MJ. Impact of endoscopic intervention in 100 patients with suspected postcholecystectomy bile leak. Gastrointest Endosc 2005;61:269-75. [CrossRef]

30. Chow S, Bosco JJ, Heiss FW, Shea JA, Qaseem T, Howell D. Successful treatment of post-cholecystectomy bile leaks using nasobiliary tube drainage and sphincterotomy. Am J Gastroenterol 1997;92:1839-43. 
ORİJINAL ÇALIŞMA - ÖZET

\section{Ameliyat sonrası safra fistüllerinin endoskopik tedavisi}

\section{Dr. Şükrü Çolak,, ${ }^{1}$ Dr. Bünyamin Gürbulak, ${ }^{1}$ Dr. Ali Fuat Kaan Gök, ${ }^{2}$ Dr. Ekrem Çakar, ${ }^{1}$ Dr. Hasan Bektaş${ }^{1}$}

${ }^{1}$ İstanbul Eğitim ve Araştırma Hastenesi, Genel Cerrahi Kliniği, İstanbul

${ }^{2}$ İstanbul Üniversitesi İstanbul Tıp Fakültesi, Genel Cerrahi Anabilim Dalı, İstanbul

AMAÇ: Safra fistülü, karaciğer ve safra yolu ameliyatlarında en sık görülen komplikasyonlardan biridir. Endoskopik retrograd kolanjiyopankreatografi (ERCP) biliyer fistüllerde tanı ve tedavi amaçlı kullanıı.ı. ERCP'nin biliyer fistüllerin tanı ve tedavisinde katkısını analiz etmeyi amaçladık.

GEREÇ VE YÖNTEM: Bu çalışmaya Ocak 2012-Aralık 2017 tarihleri arasında karaciğer ve safra yolu ameliyatlarını takiben gelişen safra fistüllerinde ERCP uygulanan hastalar dahil edildi. Hastaların demografik özellikleri, cerrahi prosedür, safra fistül lokalizasyonu, safra yolu yaralanmasının sınıflandırıması ve ERCP başarısı geriye dönük olarak değerlendirildi.

BULGULAR: Toplam 90 hastaya (37 erkek ve 53 kadın) biliyer fistül tanısı ile ERCP uygulandı. ERCP ile 87 hastada ortak safra kanalı (CBD) kanülasyonu sağlandı. Beş hastada, safra yollarının proksimal kısmı görüntülenemedi ve ortak safra kanalının tam kat yaralanması düşünüldü. ERCP'de, 44 hastada sistik kanal, sekiz hastada ortak safra kanalı, dört hastada karaciğer yatağı, iki hastada hepatik kanal bifürkasyon, yedi hastada sağ hepatik kanal ve iki hastada sol hepatik kanal düzeyinde kontrast ekstravazasyonu tespit edildi.

TARTIŞMA: Endoskopik retrograd kolanjiyopankreatografi biliyer hastalıkların tanı ve tedavisinde etkili bir yöntemdir. ERCP ile tanı konabilen ve tedavi edilebilen ameliyat sonrası biliyer fistüllerin tedavisi hastaları morbidite, mortalite ve cerrahi maliyetlerinden kurtarır.

Anahtar sözcükler: Biliyer stentler; ERCP; safra fistülü.

Ulus Travma Acil Cerrahi Derg 2020;26(1):103-108 doi: 10.14744/tjtes.2019.63667 